\title{
PENGARUH TERPAAN TAYANGAN DHARMA WACANA BALI TV TERHADAP PEMAHAMAN UMAT MENGENAI AJARAN AGAMA HINDU DI BALI SELATAN
}

\author{
I Dewa Gede Agus Priana Putra ${ }^{a, 1}$ \\ Ni Made Yuliani ${ }^{a}$ \\ Made Sri Putri Purnamawati a
}

\author{
a Universitas Hindu Negeri I Gusti Bagus Sugriwa Denpasar \\ ${ }^{1}$ Corresponding Author, email: prianasional.agus@gmailcom (Putra)
}

\section{ARTICLE INFO}

Article history:

Received: 12-01-2021

Revised: 15-02-2021

Accepted: 20-03-2021

Published: 31-03-2021

Keywords:

Exposure impact of

television show,

understanding

knowledge

\section{ABSTRACT}

The purpose of this correlational quantitative research is to determine the exposure impact of Dharma Wacana Bali TV show (X) with the indicators of broadcasting frequency, duration and attention on the understanding people about Hinduism knowledge with the indicator of three Hindu religion framework: Tattwa, Susila and upacara. The data were collected using questionnaire with 100 respondents of Bali Selatan area. After instrument test of variable $X$ that is exposure Dharma Wacana Bali TV show which consists of 8 questions and variable $Y$ that is the understanding people about Hinduism knowledge which consists of 20 questions using Corrected Item-Total Correlation to 20 samples, it can be concluded that all questionnaires are valid. Likewise reliability test using Alpha Cronbach technique, both variables are reliable. So that, further testing can be done. The data were processed and analyzed using descriptive and correlations with Software IBM SPSS V.25.0 for Windows. Descriptive hypothesis testing results show that the exposure of Dharma Wacana Bali TV Shows from the sample calculation found an average of $69.69 \%$ of the expected. The results of testing the descriptive hypothesis of the understanding people about Hinduism knowledge in South Bali from sample calculations found an average of $77.74 \%$ of what was expected. Thus the third hypothesis is that there is a significant influence of the exposure of Dharma Wacana Bali TV show on the understanding people about Hinduism knowledge in South Bali.

\section{PENDAHULUAN}

Penghayatan terhadap agama yang terdapat dalam kitab suci sangat diperlukan untuk mencapai tujuan hidup. Demikian pula dengan umat Hindu yang harus mengetahui ajaranajaran yang terkandung dalam Kitab Suci Veda untuk mencapai moksartham jagaditha.
Suatu metode diperlukan untuk menyebarluaskan pengetahuan tentang agama. Metode menyebarluaskan pengetahuan tentang agama Hindu disepakati dalam pesamuhan Agung PHDI tanggal 4-7 Februari 1988 yang dirangkum dalam bentuk buku pedoman pembinaan Umat Hindu. Metode ini disebut Sad Dharma. Sad Dharma adalah enam strategi atau 
cara dalam meningkatkan sraddha dan bhakti. Sad Dharma meliputi; Dharma Wacana, Dharma Tula, Dharma Gita, Dharma Sadhana, Dharma Yatra dan Dharma Santih.

Dharma wacana menjadi metode yang paling sering, umum dan mudah untuk dilakukan dalam menyebarkan ajaran agama Hindu. Dharma wacana menjadi metode yang digunakan oleh lembaga pembinaan umat Hindu yakni PHDI untuk mensosialisasikan ajaran agama diawal diresmikannya Agama Hindu oleh Pemerintah Republik Indonesia. Kementerian Agama juga merekrut pegawai untuk melaksanakan dharma wacana ke berbagai pelosok wilayah umat Hindu.

Namun saat ini, dikutip dari bimashindubatam.blogspot.com, Dirjen Bimas Hindu Kementerian Agama RI menyatakan bahwa ada beberapa persoalan yang dihadapi umat Hindu diantaranya adalah pemahaman umat terhadap ajaran agama Hindu yang masih cukup rendah. Agama Hindu menempati posisi ke-3 dibelakang Islam dan Kristen dari segi pemahaman umat terhadap ajaran agama. Permasalahan lainnya, sumber daya manusia penyuluh Agama Hindu yang lemah. Menurut data Kementerian PPN/ Bappenas tahun 2016 jumlah penyuluh PNS agama Hindu adalah 154 orang dan Non-PNS adalah 2.800 orang (Suryana, 2012). Padahal jumlah penduduk Beragama Hindu hasil Sensus Penduduk Tahun 2010 mencapai 4 juta jiwa atau 1 penyuluh membina sekitar 143 orang. Seorang penyuluh Agama Hindu idealnya membina 100 umat. Selain jumlahnya yang terbatas, khususnya dengan pola dharma wacana dan dharma tula, peran Penyuluh dalam membina umat memerlukan pengelolaan serta sumber daya manusia yang mumpuni. Dharma wacana saat ini mulai jarang dilakukan untuk melakukan pembinaan umat karena berbagai hambatan tersebut.

Bali TV sebagai stasiun televisi lokal di Bali pada tahun 2002 membawa angin segar menjawab permasalahan kurangnya pembinaan umat melalui dharma wacana secara langsung. Bali TV menyiarkan tayangan "Dharma Wacana" setiap hari sebanyak tiga kali sehari pada pukul 06.05 WITA, 12.05 WITA, dan 18.05 WITA. Melihat rutinitas tayangan "Dharma Wacana", hampir sebagian besar penonton televisi di Bali utamanya umat Hindu pernah menonton tayangan tersebut baik secara sengaja maupun tidak. "Dharma Wacana" bahkan menjadi tayangan favorit pemirsa Bali TV sehingga dengan cepat mempopulerkan beberapa tokoh pen-dharma wacana seperti Ida Pedanda Géde Māde Gunung, Ida Pandìta Mpu Nabe Acaryananda dan Ida Bagus Sudarsana.

Bali TV menayangkan tayangan "Dharma Wacana" dapat ditonton oleh seluruh umat Hindu di Bali Selatan. Tayangan "Dharma Wacana" tidak dapat disaksikan melalui televisi teresterial di seluruh Bali karena keterbatasan sinyal televisi. Pengaruh televisi yang cukup kuat di masyarakat dan adanya tayangan "Dharma Wacana" tentunya diharapkan mampu memberikan dampak yang positif terhadap pemahaman ajaran Agama Hindu di Bali. Meskipun cukup popular namun hingga kini belum ada peneliti yang melakukan penelitian yang menguraikan pengaruh tayangan "Dharma Wacana" di Bali TV terhadap pemahaman ajaran agama bagi Umat Hindu di Bali.

Pengaruh dharma wacana di televisi tentunya akan berbeda dengan dharma wacana langsung yang dilakukan di masyarakat, mengingat perbedaan karakteristik media yang digunakan. Media televisi memiliki keterbatasan interaksi antara pen-dharma-wacananya dengan audience atau pemirsanya dibandingkan dharma wacana secara langsung. Selain itu, dari pengamatan penulis, tayangan "Dharma Wacana" di Bali TV merupakan rekaman dharma wacana seorang tokoh pendharma wacana pada suatu acara atau upacara agama yang kemudian ditayangkan melalui media televisi. Fokus utama pen-dharma wacana melakukan dharma wacana terhadap audience yang hadir langsung pada acara tersebut bukan pada pemirsa Bali TV. Hal 
ini tentunya menyebabkan interaksi yang dibangun kurang antara pen-dharma wacana dan pemirsanya. Pemahaman ajaran agama yang diterima pemirsa Bali TV pun akan sepotongsepotong mengingat pemirsa tidak dapat langsung bertanya sesuai dengan karakteristik televisi yaitu komunikasi satu arah dari komunikator ke komunikan. Umat Hindu di Bali Selatan saat ini juga dapat mengakses informasi mengenai ajaran agama juga melalui media lainnya yang berkembang seperti media sosial Youtube, Facebook dan Instagram.

Rumusan masalah dalam penelitian ini adalah:

1. Bagaimanakah terpaan tayangan "Dharma wacana" Bali TV terhadap umat Hindu di Bali Selatan?

2. Bagaimanakah pemahaman umat mengenai ajaran Agama Hindu di Bali Selatan?

3. Apakah ada pengaruh terpaan tayangan "Dharma wacana" Bali TV terhadap pemahaman umat mengenai ajaran Agama Umat Hindu di Bali Selatan?

Penelitian ini bertujuan mengetahui hubungan intensitas penayangan sebuah acara televisi dapat memengaruhi penontonnya.

Program acara yang ditayangkan oleh stasiun televisi dapat memberikan pengaruh terpaan ke khalayaknya. Menurut Effendy (2009:124), terpaan media adalah suatu keadaan yang menimbulkan dampak pada khayalak oleh pesan-pesan yang disebarkan oleh media massa dan proses penerimaan stimulus-stimulus melalui alat indera seperti perasaan, penglihatan dan pendengaran. Pengertian terpaan media menurut Ardianto dan Erdiana (2004) dalam Putri (2014) sebagai penggunaan media baik jenis media, frekuensi penggunaan maupun durasi penggunaan.

Terpaan dalam penelitian ini meliputi frekuensi menonton tayangan di televisi, atensi menonton tayangan di televisi dan durasi menonton tayangan di televisi. Bentuk nyata dari terpaan tayangan adalah mendengar, melihat, menonton, membaca atau ikut membaurkan diri dengan isi tayangan tersebut. Frekuensi dapat diukur dengan tingkat keseringan menonton, durasi diukur dengan lama atau tidaknya tayangan tersebut dikonsumsi dan antensi diukur dengan keseriusan menonton.

\section{Dharma Wacana Bali TV}

Tayangan Dharma Wacana adalah program acara yang ditayangkan oleh Bali TV. Program acara "Dharma Wacana", sesuai dengan namanya menampilkan dharma wacana dari seorang tokoh yang telah direkam terlebih dahulu kemudian diedit dan disesuaikan dengan durasi tayangan. Dharma wacana merupakan salah satu dari enam metode pendekatan atau model pembinaan untuk menanamkan nilai-nilai Agama Hindu yang telah ditetapkan lembaga tertinggi umat Hindu (PHDI) dalam Pesamuhan Agung V tahun 1998. Dharma wacana berasal dari kata dharma dan wacana. Dharma dalam hal ini berarti agama atau ajaran-ajaran Agama Hindu dan wacana berarti ucapan atau tutur kata. Jadi dharma wacana adalah tutur kata / ceramah / membicarakan atau berceramah mengenai ajaran dharma / agama (Dhalem, 2011:44). Pengertian dharma wacana dibatasi hanya sebagai komunikasi satu arah dari komunikator (pen-dharma wacana) kepada komunikan (audience). Dharma wacana tidak mengakomodir tanya jawab atau komunikasi dua arah antara pen-dharma wacana dan audience-nya. Program acara "Dharma Wacana" disiarkan oleh stasiun Bali TV setiap hari tiga kali dalam sehari. "Dharma Wacana" disiarkan pagi mulai pukul 06.05, siang hari mulai pukul 12.05 dan sore hari mulai pukul 18.05 seusai tayangan Puja Tri Sandhya. Program acara "Dharma Wacana" tidak disiarkan secara langsung tetapi merupakan record atau rekaman yang sudah direkam sebelumnya. Program ini tidak dipersiapkan secara khusus tetapi menayangkan rekaman dharma wacana dari seorang tokoh saat mengisi dharma wacana atau dharma tula sebagai rangkaian sebuah upacara yajna disuatu tempat atau daerah. 
Pemahaman Ajaran Agama Hindu

Pemahaman ajaran Agama Hindu diartikan sebagai kemampuan seseorang untuk menafsirkan, menerangkan, memberikan contoh, serta menjalankan ajaran agama atau dharma yang disabdakan oleh Tuhan, termasuk adat istiadat dan kebiasaan hidup orang suci sebagai pedoman hidup bagi manusia dalam kehidupan. Pemahaman agama dibatasi pada tiga kerangka Agama Hindu yakni Tattwa, susila dan upacara dalam penelitian ini.

Titib (1996:258) dalam Darmawan (2019:34) menjelasakan percaya pada Tuhan (Ketuhanan) merupakan inti dari tattwa. Kepercayaan ini diterjemahkan dalam sloka Ekatwa Anekatwa Svalaksana Bhatara yang memiliki makna Brahman (Tuhan) itu dalam yang banyak, yang banyak dalam yang Esa. Agama Hindu menyebutkan Tuhan sebagai Sang Hyang Tunggal atau Sang Hyang Widhi Wasa (Tuhan Yang Maha Esa) karena meyakini bahwa Tuhan atau Brahman itu hanya satu. Karena keterbatasan pikiran manusia, Umat Hindu menyebut Tuhan Yang Maha Esa dengan banyak nama sehingga mudah imaginasinya dalam membayangkan kebesaran Tuhan.

Susila atau etika dalam Agama Hindu yang berlaku secara umum atau universal (Samaniya) Nitya Dharmasastra) diajarkan dua hal yang perlu diketahui oleh umat Hindu yaitu perbuatan baik (Subhakarma) dan perbuatan tidak baik (Asubhakarma). Kerangka dasar Agama Hindu yang terakhir atau ketiga adalah Upacara atau ritual agama. Ada dua landasan pokok umat Hindu merasa wajib melaksankan upacara sebagai pernyataan rasa bhakti dan persembahan atau pengorbanan suci kehadapan Tuhan Yang Maha Esa, yaitu; (1) Umat Hindu menyadari benar bahwa sebagai manusia dirinya penuh dosa yakni pikiran penuh dosa, perkataan penuh dosa dan perbuatan penuh dosa, serta (2) Umat Hindu yakin bahwa keberadaannya di dunia ini diliputi oleh tiga macam hutang budi (Tri Rna). Umat Hindu wajib membayar ketiga jenis hutang (Tri Rna) dengan melaksanakan lima jenis korban suci secara tulus iklhas yang disebut dengan Panca Yajna.

\section{Uses and Effect Theory}

Uses and Effects Theory pertama kali diperkenalkan oleh Sven Windahl pada tahun 1979. Uses and Effects Theory merupakan sintesis dari Uses and Gratifications Theory dan teori tradisional mengenai efek (Sendjaja, 2002:541). Alasan kebutuhan yang menyebabkan penggunaan media menurut Uses and Effect Theory merupakan salah satu dari sekian banyak faktor. akses terhadap media,pandangan atau persepsi dan harapan terhadap media menjadi faktor yang mempengaruhi seseorang pada keputusan untuk tidak atau menggunakan isi pesan media massa. (Sendjaja, 2002:216)

Penekanan asumsi dasar Uses and Effect Theory lebih kepada penggunaan media menghasilkan berbagai efek terhadap sesorang atau individu. Bagian terpenting dari teori ini terletak pada hasil dari proses komunikasi massa dan kaitannya pada penggunaan media.

\section{METODE PENELITIAN}

Penelitian pengaruh terpaan tayangan dharma wacana ini menggunakan pendekatan kuantitatif dengan design penelitian yang terfokus pada survey dengan metode deskritif korelasional. Responden dalam penelitian ini adalah pemirsa Bali TV beragama Hindu yang pernah menonton tayangan "Dharma Wacana" berdomisili di wilayah Bali bagian selatan meliputi 7 kabupaten dan 1 kota yaitu kabupaten Jembrana, Tabanan, Badung, Gianyar, Klungkung, Kabupaten Bangli, Karangasem dan Kota Denpasar. Sampel dalam penelitian ini adalah sebanyak 100 responden. Kuesioner merupakan instrumen yang digunakan dalam penelitina ini yang kemudian datanya dianalisis dengan mempergunakan regresi linier sederhana. Analisis linier sederhana digunakan untuk memprediksi perubahan variabel terikat 
apabila variabel bebas mengalami perubahan baik itu naik atau turun (Sugiyono 2018:261)

\section{HASIL DAN PEMBAHASAN Karakteristik Responden}

Penelitian ini mempergunakan 100 responden yang merupakan umat Hindu berdomisili di Kabupaten Jembrana, Tabanan, Badung, Gianyar, Klungkung, Bangli, Karangasem dan Kota Denpasar berusia 17-60 tahun yang pernah menonton tayangan "Dharma Wacana" Bali TV. Pada penelitian ini lebih banyak responden perempuan dengan presentase jumlah $52 \%$ sedangkan presentase jumlah responden laki laki sebesar 48\%. Berdasarkan usia, sebanyak 59\% responden memiliki rentang usia 17 hingga 25 tahun, 34\% responden memiliki rentang usia 26 hingga 35 tahun, 2\% responden berusia antara 36 hingga 45 tahun, 3\% responden berusia antara 46 hingga 55 tahun dan 2\% berusia antara 56 hingga 65 tahun. Pendidikan terakhir responden dominan Sarjana (S1) sebanyak 40\% dari seluruh responden, selanjutnya SMA/ Sederajat dengan jumlah responden mencapai 37\% responden, Akademi/ Diploma (D1/D2/D3/D4) dengan jumlah $17 \%$ responden, Pascasarjana (S2/S3) sebanyak 5\% responden, dan SMP/ Sederajat sebanyak $1 \%$.

Berdasarkan pekerjaan $34 \%$ merupakan Pelajar/Mahasiswa, 36\% responden bekerja sebagai Karyawan Swasta, $12 \%$ responden merupakan Pegawai Negeri Sipil (ASN), $10 \%$ responden berprofesi sebagai pedagang atau Wiraswasta, 1\% responden merupakan Petani, 2 \% responden merupakan bekerja sebagai Guru, 3\% responden merupakan Pegawai Pemerintah Non ASN, dan masing masing $1 \%$ berprofesi sebagai Ibu Rumah Tangga (IRT), dan belum bekerja.

Berdasarkan durasi menonton televisi, 76\% memiliki durasi menonton televisi selama 1 hingga 2 jam dalam sehari, 19\% responden menghabiskan waktu 3 hingga 4 jam untuk menonton televisi per hari dan $5 \%$ responden menghabiskan waktu lebih dari 4 jam untuk menonton televisi perhari. Berdasarkan program televisi favorit, $47 \%$ menjadikan program televisi berita sebagai program favoritnya saat menonton televisi. 11\% responden memiliki program televisi favorit sinetron. $5 \%$ responden memiliki program televisi favorit reality show, $4 \%$ memiliki program favorit variety show. Program televisi talkshow dimana program Dharma Wacana termasuk didalamnya dipilih oleh 28\% $1 \%$ responden memilih program film dan $4 \%$ memilih kartun sebagai program televisi favoritnya. Berdasarkan sumber mendapatkan pengetahuan agama, 37\% menyatakan bahwa sumber mendapatkan pengetahuan Agama Hindu dari media sosial. Buku agama menempati posisi terbanyak kedua dengan dipilih oleh $35 \%$ responden. Televisi berada di posisi ketiga dengan persentase mencapai $21 \%$ responden. Dharma Wacana di Pura menempati posisi selanjutnya dipilih oleh $5 \%$ responden dan Koran dipilih oleh $2 \%$ responden.

\section{Terpaan Tayangan Dharma Wacana Bali TV}

Hasil analisis deskriptif diketahui bahwa sebagian besar umat Hindu di Bali Selatan memiliki kualitas terpaan Tayangan Dharma Wacana sedang, dimana terdapat $43 \%$ responden kategori sedang, $40 \%$ responden kategori tinggi, $8 \%$ responden kategori sangat tinggi dan hanya $9 \%$ responden berada pada kategori rendah dari 100 Umat Hindu yang menjadi subjek penelitian. Rata-rata Umat Hindu di Bali Selatan yang memiliki kualitas terpaan Tayangan Dharma Wacana Bali TV yang sedang mengindikasikan Umat Hindu memiliki frekuensi menonton Tayangan Dharma Wacana Bali TV cukup baik, durasi menonton Tayangan Dharma Wacana yang cukup baik serta atensi terhadap Tayangan Dharma Wacana yang cukup baik. Secara komulatif, nilai terpaan Tayangan Dharma Wacana Bali TV Umat Hindu di Bali Selatan mencapai 69,69\% dari yang diharapkan. Atensi menjadi indikator terpaan Tayangan 
Dharma Wacana yang memiliki kualitas tertinggi dari indikator lainnya. Kualitas indikator atensi mencapai $72,5 \%$ dari yang diharapkan. Sedangkan indikator frekuensi menonton Tayangan Dharma Wacana Bali TV hanya mencapai 69,25 \% dari yang diharapakan dan kualitas indikator durasi menonton Tayangan Dharma Wacana Bali TV hanya mencapai 64,5\% dari yang diharapkan.

\section{Pemahaman Umat mengenai Ajaran Agama Hindu di Bali Selatan}

Hasil analisis deskriptif diketahui bahwa sebagian besar Umat Hindu di Bali Selatan memiliki kualitas pemahaman mengenai ajaran Agama Hindu tinggi. Hal ini ditunjukan data terdapat 82 responden dengan persentase $82 \%$ berada pada kategori tinggi, 10 responden dengan persentase $10 \%$ berada pada kategori sangat tinggi dan 8 responden dengan persentase $8 \%$ berada pada kategori sedang dari 100 Umat Hindu yang menjadi subjek penelitian. Secara komulatif, nilai pemahaman Umat mengenai ajaran Agama Hindu di Bali Selatan mencapai 77, $74 \%$ dari yang diharapkan. Ratarata Umat Hindu di Bali Selatan yang memiliki kualitas pemahaman mengenai ajaran Agama Hindu mengindikasikan umat Hindu memiliki pemahaman tentang tattwa, susila dan upakara baik. Pemahaman tentang upakara menjadi indikator pemahaman ajaran Agama Hindu yang memiliki kualitas tertinggi dari indikator lainnya. Kualitas indikator pemahaman upakara mencapai 90, 9\% dari yang diharapkan. Sedangkan indikator pemahaman mengenai susila Agama Hindu hanya mencapai nilai 76, 3\% dari yang diharapakan dan kualitas indikator pemahaman mengenai tattwa hanya mencapai $70,4 \%$ dari yang diharapkan atau yang paling rendah dari indikator lainnya.

Pengaruh Terpaan Tayangan Dharma Wacana Bali TV (X) terhadap Pemahaman Umat Mengenai Ajaran Agama Hindu (Y) di Bali Selatan
Hasil penelitian menunjukan bahwa antara variabel terpaan Tayangan Dharma Wacana Bali TV dengan pemahaman umat mengenai ajaran Agama Hindu terdapat koefisien korelasi sebesar 0,632 dengan signifikansi 0,000. Hal tersebut berati bahwa ada korelasi yang positif dan kuat antara terpaan Tayangan Dharma Wacana Bali TV terhadap pemahaman umat mengenai ajaran Agama Hindu. Dari hasil analisis regresi linier sederhana ditemukan koefisien determinasi $(R$ Squere) sebesar 0,399. Data ini mengandung arti pengaruh terpaan Tayangan Dharma Wacana terhadap pemahaman umat mengenai ajaran Agama Hindu sebesesar 39, 9 \%. 60, 1 \% sisanya dipengaruhi variabel lain yang dapat diteliti dalam penelitian lain. Hasil analisis output coefficient diperoleh persamaan antara terpaan Tayangan Dharma Wacana Bali TV (X) terhadap pemahaman umat mengenai ajaran Agama Hindu (Y) yang berbentuk : $Y=42,669+0,875 \mathrm{X}$

Konstanta sebesar 42,669 dalam persamaan memiliki arti nilai konsisten variabel terikat (pemahaman) adalah sebesar 42,669. Meskipun kualitas atau skor Terpaan Tayangan Dharma Wacana Bali TV umat Hindu di Bali Selatan sebesar 0, persamaan tersebut memprediksi skor atau nilai pemahaman umat masih tetap diperoleh dengan nilai 42,669. Hal ini menunjukan bahwa pemahaman umat mengenai ajaran Agama Hindu tidak hanya dipengaruhi oleh terpaan tayangan Dharma Wacana Bali TV namun juga hal-hal lain yang belum diteliti dalam penelitian ini. Koefisien regresi $\mathrm{X}$ bernilai positif dengan nilai 0,875 dapat diterjemahkan setiap peningkatan $1 \%$ nilai terpaan Tayangan Dharma Wacana makan nilai pemahaman umat mengenai ajaran Agama Hindu akan meningkat atau bertambah 0,875 .

\section{SIMPULAN}

Dari pembahasan di atas dapat disimpulan beberapa hal sebagai berikut :

1. Kualitas terpaan tayangan Dharma Wacana Bali TV terhadap Umat Hindu di Bali Selatan adalah sebesar $69,69 \%$ dari yang 
diharapkan dan termasuk dalam kriteria sedang.

2. Tingkat kualitas pemahaman umat mengenai ajaran Agama Hindu di Bali Selatan adalah sebasar 77,74 \% dari yang diharapkan dan termasuk dalam kriteria tinggi.

3. Ada pengaruh yang positif, kuat dan signifikan antara terpaan tayangan Dharma Wacana Bali TV dengan pemahaman umat mengenai ajaran Agama Hindu di Bali Selatan dengan korelasi sebesar 0,632

\section{DAFTAR PUSTAKA}

Adiputra, Rudia. 2017. Pemertahanan Agama Hindu di Desa Adat Kuta sebagai Presentasi Kampung Global (Disertasi). Universitas Udayana Denpasar

Amanda, Ras, Dewi Yuri Cahyani. 2015. Pola Konsumsi Siaran Televisi di Denpasar : Statistik Deskriptif. E.Jurnal Universitas Udayana Denpasar. https://ojs.unud.ac.id/index.php/jekt/arti cle/view/16508 diakses pada 2 Januari 2020 pukul 20.00 WITA

Bungin, Burhan. 2009. Sosiologi Komunikasi, Teori Paradigma, dan Diskursus Teknologi Komunikasi di Masyarakat. Jakarta : Kencana Pernada Media Group

Darmawan, I Gusti Ngurah Aan. 2019. Tesis Pengaruh Menonton Acara Siaran Siraman Rohani Agama Hindu Di LPP TVRI Bali Terhadap Perilaku Beragama Di Kota Denpasar. Program Studi Magister Ilmu Komunikasi Hindu Program Pascasarjana Institut Hindu Dharma Negeri Denpasar.

Dhalem, I Gusti K. 2011. Buku Pedoman Penyuluh Agama Hindu. Fakultas Dharma Duta Institut Hindu Dharma Negeri Denpasar

Effendy, Onong Uchjana. 2009. Komunikasi Teori Dan Praktek. Bandung: PT Remaja Rosdakarya.

Febrina, Ruth, Ni Made Ras Amanda Gelgel, Ade Devia Pradipta. 2019. Pengaruh Terpaan
Tayangan "86" di Net.TV terhadap Persepsi Khalayak di Kota Denpasar tentang POLRI. E.Jurnal Universitas Udayana Denpasar. https://ojs.unud.ac.id/index.php/komunik asi/article/view/46414 diakses pada 6 Januari 2020 pukul 19.00 WITA

Ghozali, Imam. 2006. Aplikasi Analisis Multivariate dengan Program SPSS. Semarang: BP Undip

Gulo, W. 2004. Metodelogi Penelitian. Jakarta: Grafindo.

Hastuti, Sri. 2013. Efektifitas Iklan Layanan Masyarakat Di Televisi. Jurnal Ilmu Komunikasi. Universitas Riau.

Jannah, Lina Miftahul \& Bambang Prasetyo. 2008. Metode Penelitian Kuantitatif, Jakarta: PT Raja Grafindo Persada

Kriyantono, Rachmat.2008. Teknik Praktis Riset Komunikasi. Jakarta : Kencana Prenada Media Group.

Morissan. 2014. Teori Komunikasi Individu Hingga Massa. Jakarta: Kencana Prenadamedia Group.

Putri, Yenny.2014. Terpaan Program Berita Reportase Investigasi di Trans TV terhadap Persepsi Ibu Rumah Tangga di Kecamatan Tenggarong. E Journal Ilmu Komunikasi. 2(3) 109-119 https://ejournal.ilkom.fisipunmul.ac.id/site/?p=1440 diakses pada 4 Januari 2020 pukul 18.00 WITA

Sendjaja, Djuarsa. 2002. Teori Komunikasi. Jakarta: Pusat Penerbitan Universitas Terbuka

Sugiyono .2018. Metode Penelitian Kuantitatif.Bandung: Alfabeta.

Suhardana, Komang. 2008. Subha Asubhakarma Perbuatan Baik dan Tidak Baik. Surabaya: Paramitha.

Suhardana, Komang. 2010. Kerangka Dasar Agama Hindu, Tattwa Susila Upacara. Surabaya: Paramitha.

Suryana, Dayat. 2012. Bali dan Sekitarnya.

Tim Penyusun.1999. Pedoman Penyuluh Agama Hindu. Bidang Urusan dan Penerangan 
Agama Hindu Kantor Wilayah Departemen Agama Propinsi Bali Denpasar.

Wahyuni, I Gusti AAI. 2017. Jurnal Respon Siswa

SMA Dwijendra Terhadap Program Acara

Dharma Wacana Radio Komunitas

Dwijendra. Jurnal Penelitian Agama Hindu Institut Hindu Dharma Negeri Denpasar Vo.

$1 \quad$ No. 2 Oktober 2017

http://ejournal.ihdn.ac.id/index.php/IPAH /article/view/300/264 diakses pada 2 Januari 2020 pukul 19.00 WITA

Wahyuni, Rikha. 2013. Jurnal Analisis Isi Dharma Wacana Agama Hindu Melalui Bali TV Dalam Perspektif Pendidikan Karakter (Studi Kasus PenDharma Wacana Ida Pandita Mpu Jaya Acaryananda).Jurnal Pendidikan Sejarah Widya Winayata Vo. 1, No 1 Universitas Pendidikan Ganesha Singaraja.

https://ejournal.undiksha.ac.id/index.php LJPS/article/view/1024 diakses pada 2 Januari 2020 pukul 19.30 WITA

http://bimashindubatam.blogspot.com/2017/0

3/dirjen-bimas-hindu-pembinaan-umathindu.html diakses pada 3 Januari 2020 pukul 18.45 WITA 